Tjalling C. Koopmans Research Institute

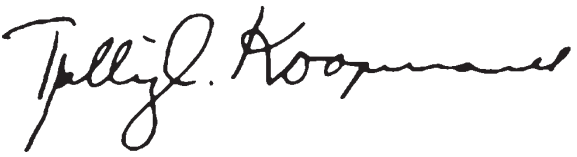

Discussion Paper Series nr: 04-12

\title{
Increases in Female Labour Force Participation in Europe: Similarities and Differences
}

Jan Dirk Vlasblom Joop J. Schippers 


\section{Tjalling C. Koopmans Research Institute Utrecht School of Economics \\ Utrecht University}

Vredenburg 138

3511 BG Utrecht

The Netherlands

telephone $\quad+31302539800$

fax $\quad+31302537373$

website www.koopmansinstitute.uu.nl

The Tjalling C. Koopmans Institute is the research institute and research school of Utrecht School of Economics.

It was founded in 2003, and named after Professor Tjalling C. Koopmans, Dutch-born Nobel Prize laureate in economics of 1975.

In the discussion papers series the Koopmans Institute publishes results of ongoing research for early dissemination of research results, and to enhance discussion with colleagues.

Please send any comments and suggestions on the Koopmans institute, or this series to P.vanDriel@econ.uu.nl

ontwerp voorblad: WR IK Utrecht

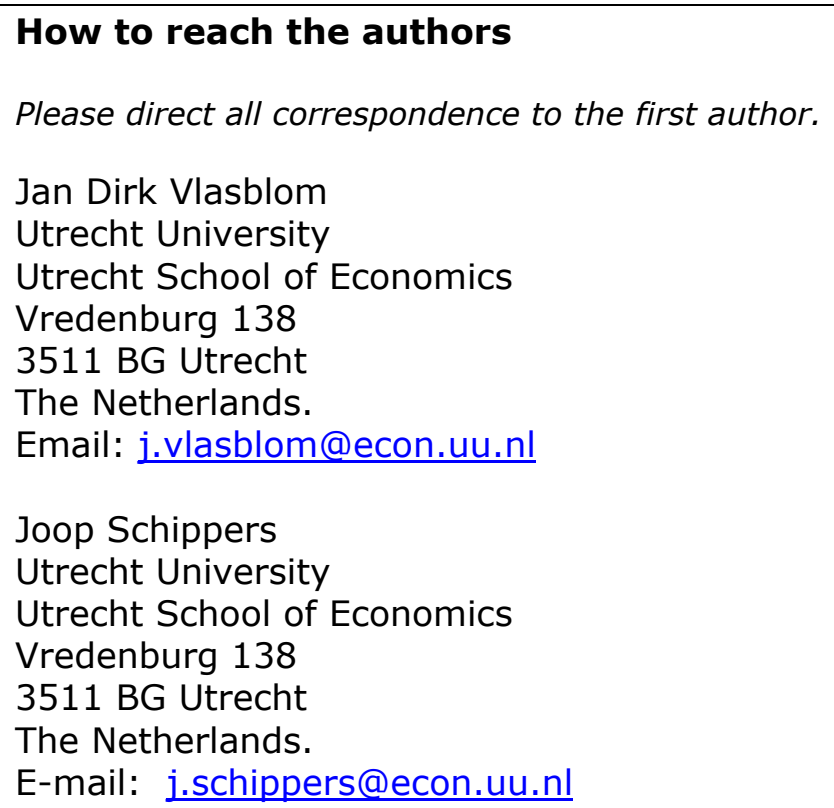




\title{
Increases in female labour force participation in Europe: similarities and differences
}

\author{
Jan Dirk Vlasblom \\ Joop J. Schippers \\ Utrecht School of Economics \\ Utrecht University \\ March 2004
}

\begin{abstract}
Low educational levels and the effect of children are recognized as the most important factor for low female participation rates. Over the last decades, female labour supply in Europe has shown a large increase. This may be the result of changes in the level of education or fertility. It is also possible that it is due to changes in behaviour, as influenced by the social and institutional context. Our results show that increases in participation rates cannot be explained by changes in either educational level or the number and timing of children. Female labour supply increases for all educational levels and for both women with and without children. In other words, it is mainly changes in behaviour driving the increase in participation rates over the last decades.
\end{abstract}

Keywords: female labour supply

JEL classification: J22 


\section{Introduction}

During the sixties and the seventies the 'average' working woman was a young woman without children. At the turn of the century working women in Europe comprise both mothers and women without children, young and older women and women of different educational levels. (For an extensive review of these trends, see e.g. Rubery, Smith, Fagan and Grimshaw, 1998). The changes in female labour force participation and in the composition of the female labour force reflect two kinds of changes. On the one hand the characteristics of the female population have changed over time. Women have become higher educated, overall birth rates have decreased, the percentage of childless women has increased, while the age at which women become a mother for the first time has increased all over Europe. So, even if today's generations of women were to show similar participation behaviour as women from the past, participation patterns would have changed over time. However, on the other hand we also see that women nowadays show different behaviour compared to women with similar characteristics than in the past. For instance, women with small children were a rarity in the labour market until the early nineties of the twentieth century. One decade later it is no longer an exception for women with young children to be active in the labour market. So, even when characteristics of the female population would not have changed, participation patterns would have done so. Changes in behaviour of women with specific characteristics reflect both changing preferences and changing restrictions. An increasing number of women holds the opinion that motherhood is not the only goal to strive for in life and that a professional career is also important to fulfil ones needs and to exploit ones talents. Next to (or as a result of) their own changing opinions and preferences society has changed too. Many EU-countries have developed childcare policies that allow women with young children to be active in the labour market and have a professional career. This, among other things, resulted in a change of the restrictions an individual woman is faced with.

Even though female labour market participation rates have increased throughout Europe not all EU-countries show a similar picture. In some countries the composition and the characteristics of the female population has changed more than in other countries. The same holds for the changes in behaviour. In this article we want to establish in a quantitative manner the causes for the differential changes in female labour market 
participation for six of the EU-countries over the last decade: is it mainly a compositional effect or is the behavioural effect the dominating force behind the increasing female labour market participation? In addition we try to relate the behavioural changes to changing institutional arrangements.

We will analyse changes in participation levels in six European countries, based on data from the Labour Force Survey of Eurostat. These countries are (West-) Germany, the Netherlands, The UK, France, Spain and Italy. Together these countries are thought to present a representative picture of changes in (Western) Europe. We do not include any transition economies as the situation in these countries differs considerably from the situation in more stable economies. We therefore also exclude (former) East Germany from our analysis. To give a complete picture of European trends we would have liked to include also one of the Scandinavian countries. However, our data source (the LFS) did not allow us to do so. Using these data we estimate a model describing the relation between female labour force participation and characteristics for two years, 1992 and 1999. Next, a decomposition analysis of changes in labour force participation rates over this decade is performed. This decomposition enables us to tell whether the changes are due to changes in the characteristics of the population or to changes in labour supply behaviour. Although a decomposition between countries is also possible, the article does not go into the differences in participation rates between countries, but focuses mainly on changes over time within countries.

In Section 2 we show some of the trends over the last decade with respect to educational attainment, organization of the household, and female labour supply. In Section 3 we go briefly into the factors that affect the female labour supply decision. In Section 4, we present some of the technical details, while in Section 5 we give the estimation results of a labour supply model. We use the results of this model to compute some decomposition analyses, the outcomes of which are presented in Section 6. Finally, Section 7 concludes. 


\section{Changing characteristics of the female population}

Over the last decade, substantive changes took place in the composition of the female population. First, women have increasingly higher educational levels. Even over a short period as a decade, the shifts are clear. As shown in Table 1, in all countries included in this study, the general level in education has increased. This increase is on the one hand the result of changing preferences towards working; on the other hand it will be the cause of an increase in participation. The level of education will in general not be completely exogenous with respect to the decision to work.

[Table 1]

An other change is that men and women show different behaviour with respect to partnership formation. In the past, the normal pattern was marriage, nowadays, cohabitation is more and more accepted. Also, the number of women not living with a partner changed over the last decades. The LFS does not provide information on the percentage for unmarried cohabiting women, but we have information on the percentage of women without a partner.

In most countries fertility decreased, perhaps as a result of higher educational levels, or as a separate trend. Not only the size of the 'completed family' decreased but also the timing of children changed. The first child is more and more 'delayed', resulting in an increased period that is 'childless'. In Table 2, it is shown which percentage of women in a certain age category is living in a household without children. In the early age categories, changes in the numbers are mainly the result of changes in the number of children born and the timing of their birth. In the older categories, the changes are due to changes in the age children leave the household. Mothers' age at first birth has increased in all countries. In the southern countries it has changed only by 0.3 years, while in the northern part the change has been much larger: in France, the Netherlands and the UK, the change was about 1 year. As a result of this, an increasing part of the younger women is without children. In the Netherlands, even 71 percent of women aged 25-29 are without children. The largest increase of childlessness in this age category has occurred in Spain and France, where there has been a 14 percentage points increase in the number of women without children. 
Not only the timing of children, but for some countries also the average number of children per woman changed over time, possibly as a result of the delay in child bearing. In Table 3, the average number of children per household is shown (including households with no children). Note that this table shows the number of children present in the household, not the total number of children born to a woman. It can be seen that in all countries, for the younger women the number of children in the household decreased during the last decade. Especially in southern Europe the shift has been large. As to northern Europe, it seems as if the shift reflects merely a change in the timing: for the age category 35-39 the number of children in the household is comparable to the number of earlier generations. However, in southern Europe, the delay of childbearing apparently goes together with a reduction in fertility: the generation 35-39 in 1999 has considerably less children than the women in the same age group of a generation before.

[Table 3]

Finally, we present some information on female labour force participation. In this article we define participation as actually working at least one hour per week. We do not go into changes with respect to full-time and part-time work. Table 4 shows that over the last decade, an increase in female labour force participation is found in the six countries in our study (see the bottom line of Table 4), with the Netherlands showing the largest increase during the period 1992 - 1999.

[Table 4]

\section{Female labour market behaviour}

Economic theory has provided us with a number of structural models of female labour supply. In these models, it is usually assumed that women gain utility from income, leisure time and children. However, all three do cost time, and leisure and children also cost money, while income can be earned by working for pay. The possibilities women have are given by the availability of suitable work, and their possibility to get such a job. The restrictions women face are given by the time- and budget restrictions, but also by e.g. discrimination in the labour market. 
Higher education contributes to the development of tastes that favour women's desire to have their own professional career and develop their personal talents, not only as a mother, but also as a professional (Hakim, 1995). Besides, higher education also stimulates the development of more modern norms concerning the combination of paid labour and unpaid care (e.g. Pott-Buter, 1993). This level of education is also a proxy for her (expected) wage rate when she enters the labour market. As higher (potential) wages are expected to increase her participation rate, we expect participation rates to be higher for women with higher educational levels. The higher a woman's education the higher will also be her income foregone when she does not participate in the labour market (Dankmeyer, 1996; Joshi, 1990, 1994; Joshi, Macran and Dex, 1996; Mertens, Van Doorne-Huiskes, Schippers and Siegers, 1998). So, higher education contributes to higher participation rates in at least three ways.

Family composition and stage in family cycle have a strong effect on female labour force participation rates. At young ages women will be participating in education, and gradually entering the labour market. In many European countries, the birth of a first child is a major reason for women to leave the labour market. Although many of them do return after some time, especially low-educated women do hardly return to the labour market after childbirth (see e.g. Dankmeyer, 1996; Joshi et al., 1996; Mertens et al., 1998; Wetzels, 1999). Age may be an indicator for these stages in the family cycle. Apart from this 'true' age-effect, in a cross-sectional analysis age will pick up generation effects. As younger cohorts show a more career-oriented attitude than older generations we expect age to show a strong negative correlation with participation rates.

However, the most important proxy for stage in family cycle is the number and age of the children. It is expected that children affect labour supply quite strongly. First, the presence of children affects labour supply: as soon as children are present, unpaid work at home will take more time, which will probably reduce labour supply. Therefore, also the number of children affects labour supply. The more children there are in the household, the lower female participation rate is expected to be, as women are faced with increasing problems to combine children and paid work. It may be possible to combine one child with work, even at low ages of the child but this will become more difficult when there are already some older children present. Also the age of the children may be of importance: the younger the youngest child the lower the 
participation rate will be, as younger children require more time and cannot be left alone. The older the children become the easier it will be to combine work and family. Finally, the effect of age and number of the children may also depend on the age difference between the children. There may be some interaction-effects between the children: when there are one or two relatively older children present, these children may provide some of the childcare for their younger brothers or sisters. This will presumably increase labour supply of the mother. On the other hand, the larger the age difference between the children, the longer will be the period in which young children are present in the household. This, in turn will probably lower labour supply of the mother.

Apart from own preferences, behaviour is also influenced by restrictions. Part of these restrictions is on an individual level: income and time restrictions within the household. However, the institutional context can also provide strong incentives or restrictions on individual behaviour. The institutions of most importance when it comes to female labour market participation are the tax system, the system of leave arrangements and the childcare facilities. In the literature it has been shown that taxation systems that are household-based (like the German one) lead to lower participation rates than individualbased systems such as the Swedish system, and -to some extent- the Dutch system (Gustafsson, 1992; Vlasblom, De Gijsel and Siegers, 2001).

The level of childcare or leave arrangements will have effects on labour supply. It is generally thought that more of these facilities will increase female labour supply, as the combination of work and family will become easier for the effects of children depend very heavily on the restrictions the households are faced with (Den Dulk, 2001). The easier the access to childcare, the smaller the effect of children on labour supply will be - other things equal. Not only childcare will be of importance; other regulations such as the existence of paid leave in order to care for sick children and the characteristics of the educational system also matter. These regulations will also make the combination easier, and thus increase labour supply. The same holds for other regulations that increase role sharing and equal opportunities for both sexes.

The presence of anti-discrimination legislation, legislation concerning equal opportunities, affirmative action or even contract compliance differs between countries. This also holds for rules and legislation with respect to leave arrangements, career 
breaks etc. Part of these rules may not be included in government legislation, but elements of collective agreements negotiated between (organisations of) employers and unions. So, changes in institutions - though difficult to measure - may also contribute to higher female labour force participation rates,

One of the restrictions not mentioned before is the business cycle. When labour market is loose, individuals are willing to work, but not able to find a (suitable) job. As a result of this, actual participation levels will be lower than preferred participation levels (the discouraged worker effect). However, in this case there may also be the added worker effect: when the bread winner becomes unemployed, other household members - mostly the female partner - may try to increase labour force participation in order to keep income at the necessary level. On the other hand, when there is a labour shortage, individuals may be offered a job without actually being looking for it. In that case, they will perhaps accept a job that they would not have looked for when it was not offered to them. In that case, actual participation levels may be higher that ex-ante preferred levels (the encouraged worker effect). We should include e.g. the official unemployment rates to correct for this effect. This leads to empirical problems; first, as the added-worker and the (en)discouraged worker effects also affect the levels of registered unemployment, the unemployment rate is a perfect variable to measure this effect. Secondly, we estimate our models year by year for each country, without pooling. In other words, the unemployment rate will be equal for all individual observations: the effect will not be identified.

\section{Data and computational details}

The data we use for our empirical analysis are provided by Eurostat, and are based on the European Labour Force Survey (LFS). We use data from two years: 1992 and 1999. The yearly samples can be interpreted as representative samples of the total population. The data are weighted data that Eurostat considers to be representative for the total (female) population. The advantage of using this data set is that for a number of years data are available, using the same (or comparable) definitions over years and over countries. However, using the LFS also has a few disadvantages. The first is that the database is strictly individually based. A number of individual characteristics are known, such as age, household status, level of education (in a 3-level classification), 
number of children, year of birth of the children, labour market status, working hours, etc. However, it is impossible to get precise information on characteristics of household members, such as age and educational level of a partner. Also, as a result of the data being comparable over countries, information needed to compute the exact (net) wages of women is absent. This implies that it is impossible to model the exact effects of participation decisions on the use that is made of e.g. state provided child care, the costs of this child care (as this is income dependent in most countries) etc. This implies that it is impossible to estimate full structural models of labour supply that take account of all possibilities and restrictions women are confronted with. Although data are available for several years it is not possible to follow individuals over time (even for those countries where the data are based on 'true panels'). Comparisons over time are therefore always comparisons based on pseudo-cohorts. Finally, due to data-regulations at Eurostat, the analyses cannot be done at the individual level. Data are available in the form of contingency tables for a restricted number of variables, which thus lead to aggregated, grouped data.

As we are interested in the labour market behaviour of women, we restrict ourselves to the group of (potential) workers. In other words, those women that are out of full-time education, and not in the retirement age: those aged 25 to 59. Also, we restrict our sample to the women for whom the combination of family and participation is relevant. We will therefore focus on women that do have a partner, and do not live with their parents (or the parents of her partner).

In principle, we would like to include the wage, as this is an important explanatory factor for female labour force participation. However, this information is not present in the data set we used for this study. The same holds for the characteristics of the partner of the woman, and especially his income. Both own wage rate and other household income are important factors in explaining participation rates (See a.o. Grift, 1998; Vlasblom, 1998). Omitting these variables can cause some omission bias. However, educational level and age are included. As wage rates can be explained by educational level and age, these variables will act as instrumental variables for the wage. There are no instrumental variables available for the partner's income. 
We use a reduced form model of labour supply in which labour supply is explained by the characteristics of women, including the number and spacing of the children. For the empirical specification, we use a bivariate logit model to explain the participation rate of women. As we use grouped data, we use a weighted specification of this model in which every cell is weighted with the number of observations in that cell. In these reduced form models, we can not directly incorporate the institutional system. The model does therefore not allow us to compute the effects of changes in this institutional system. However, changes in this system will result in changes in the estimated parameters of the model, as these reflect the 'combined effect' of preferences and restrictions.

Using the estimation results of this model, we can compute whether the observed changes in participation can be related to changes in the explanatory characteristics such as educational level, number and timing of children etc, or to the effect the educational level and the children have on labour supply using a decomposition analysis (Oaxaca, 1973). Henkens, Grift and Siegers (2002) use this kind of approach to explain differences in labour supply behaviour between married and cohabiting women in the Netherlands in 1989 and 1998. We, however, do not use a formal decomposition analysis but our approach is very much based on this kind of analysis. We follow the approach of Van den Berg and Grift (2001), who analyzed the evolution of union membership over time. We compute predicted labour supply for the average individual in 1992 and change in a number of steps both the value of the explanatory variables and the estimated parameters to the values in 1999. Computing predicted participation rates for each step, we can get an idea of the relative importance of each separate factor in explaining the total change in participation rates.

\section{Regression analyses}

The estimation results of the labour supply model can be found in Tables 5 and 6 for the years 1992 and 1999 respectively. As explanatory variables we include age, educational level, the number of children present in the household, and the age of the youngest child in the household, and the age difference between the youngest and the oldest child. We also include interaction terms for both number of children and age of youngest child with the age of the woman. As the general patterns between the two years do not differ, 
we discuss the estimation results for 1999 only, and compare those to the results of 1992 when necessary.

[Table 5]

[Table 6]

Comparing the results for the six countries we see a number of similarities. For all countries there is an age-pattern in which participation rates first rise with age and after a certain age decline again. The age at which the maximum is reached, however, differs. It is relatively low in Germany and the Netherlands (31 years of age), and relatively high in the Mediterranean countries including France (about 38 years of age). This reflects the fact that for Dutch women participation rates are highest for the youngest cohorts, and fall gradually for older cohorts, while in the southern countries women enter the labour market relatively late. The effect of age changes over time: compared to the 1992 results, the age profile in Germany, France, Italy and the Netherlands shifted to the right. The shift has been largest in Germany and the Netherlands. This implies that the younger cohorts show higher participation rates, and also that the younger cohorts do not decrease their participation rates as much as the older cohorts did. In Spain the age profile shifted to the left, indicating that younger cohorts have left the labour market sooner than the older cohorts have done and also at a much higher speed than the estimated age-profile suggests. However, the age at which the maximum participation rate is reached is still higher than the one observed in the northern European countries. This shift to the left can perhaps be explained by the fact that the economic situation in Spain deteriorated during the last decade forcing workers with the weakest positions to withdraw from the labour market. In the UK, on the other hand, the age profile remained stable. It should be stressed that due to the fact that the data are crosssectional, the age pattern reflects a generation effect, and probably not a 'true' ageeffect.

The effect of education is comparable in all countries: there is a difference in participation rates between high- and low-educated women, with the low-educated women working significantly less than the high-educated women. This difference is very large in Spain and Italy, and relatively small in Germany and the UK. The low participation rates for low-educated women confirm our hypothesis that low-educated women do not have enough opportunities to stay in the labour market or have to make 
relatively large costs to do so. This suggests that higher participation rates of women should be realized by increased educational levels of women. Compared to 1992, the position of the intermediate educated women changes: the difference in participation rates between low- and medium-educated women became larger while that between high- and medium-educated women became smaller. This implies that the mediumeducated women are becoming 'more like high-educated women' with respect to participation rates, again stressing the fact that the low-educated women are more and more 'lagging behind'. Also the difference between the high- and the low-educated women changed. Both in 1992 and 1999 the low-educated women worked less than women with intermediate education, but on average the difference has increased. This is especially so for West Germany, France and the UK. This suggests that while women with intermediate education 'closed' the gap with the high-educated women, the loweducated women where not able to do so. Therefore, there relative position towards intermediate-educated women has deteriorated. This confirms that low-educated women did benefit the least from the 'new possibilities' for women on the labour market (Joshi et al., 1996).

The number and age of children proved to be an important factor in the decision to participate. When the first child is born, participation rates are going down considerably. Especially in Germany, the Netherlands and the UK, the participation probability of women with at least one child is lower than participation of women without children. When subsequent children are born, participation rates are again decreasing. In all countries, the effect of subsequent children is smaller than the effect of the first child, indicating that the birth of subsequent children does lead to a change in the participation decision, but not as large as the change at the first birth. France and Italy are the exception to this. In these countries, the impact of a subsequent birth is larger than that of the first birth. This suggests that in these countries, problems of combining motherhood and family severely increase when the family becomes larger, while in the other countries, an increase in the number of children does increase problems, but not very much.

As described in the previous section, it is to be expected that not only the number of children determines labour supply but also their age. The results do confirm this hypothesis for some countries: participation rates are positively correlated to the age of 
the youngest child, the correlation being highest in the UK. So, when the child gets older, the negative impact of the child's presence is gradually mitigated. This negative effect of the age of the youngest child is smaller in the Mediterranean countries. An explanation may be that in Mediterranean countries parents rely heavily on the family network for (informal) childcare, which makes mothers' labour market participation relatively independent on the age of the children. Again, the effect is also dependent on the age of the mother. The older the woman, the lower her participation rate is (given the age of the child). This may indicate that women of older generations show a smaller increase in labour supply when the child grows older. In other words: there seems to be a higher return to the labour market (or less withdrawal) for younger than for older generations. The effect may, however, also be interpreted as a 'true' age effect, indicating that older mothers are less likely to re-enter the labour market, possibly due to discrimination or lack of proper human capital.

Finally, there is an effect of the age difference between the children. The results show that in all countries, except the Netherlands, a larger difference in age between the youngest and the oldest child leads to higher participation rates. We expected the duration of the period with small children to be the most important factor in influencing labour supply; our estimation results point in the direction of the 'intensity' of this period. In the Netherlands, however, a longer period with young children leads to lower participation rates of women. This may have to do with the strong tendency among Dutch mothers to care themselves instead of relying too much on different forms of formal or informal childcare. The effects of the age difference, either positive or negative, are not very strong.

Compared to 1992, it shows that the effects of children changed. However, while the other changes were roughly comparable over Europe, with respect to children the changes show no clear pattern. The effect of the first child decreased (slightly) in Germany and the Netherlands. It increased in Spain, France and Italy. In the UK it remained constant. The effect of subsequent children increased in Spain and Italy, the Netherlands and the UK, it remained more or less constant in Germany and France.

\section{Unravelling the changes in female participation rates}


The estimated models make it possible to study the effect of women's characteristics (like age, being a mother, having a higher education) on labour supply. In the previous section it was shown that the effects of these characteristics changed over time. However, also the characteristics of the population change. Over the last decades, the educational level of women has risen and the number of children declined. This change in characteristics can also have contributed to the increase in female labour supply. In Table 7, we present predicted labour force participation rates for nine selected hypothetical individuals, differing in educational level and the number of children for both 1992 and 1999. These results illustrate to which extent children and educational level affect female labour supply. By comparing the predicted participation rates over time, we get an impression of the changes in labour supply behaviour, given the characteristics.

\section{[Table 7]}

For all six countries we can see that the presence of one or more children in the household lowers the participation probability of women. The effect of children on participation is large in all countries, except for France. The table shows that in Germany in 1992 the participation rate of medium educated women is 83 percent for women without children and 63 percent for women with one child. In other words: the reduction in participation rates due to the first child is about 20 percentage points. For low educated women this reduction is slightly larger, while for high-educated women the reduction is slightly lower. In the Netherlands, the pattern is comparable to that in Germany, while Spain, Italy and the UK show lower, but still considerable, negative effects of around 10 and 5 percentage points. In France the results indicate a slight increase in participation rates due to the first child.

Over time, changes in behaviour took place that resulted in increases in female participation rates. However, the increases are not equal for women of different characteristics. As a result, the 'penalty' for having a child changed, and the size of this change is dependent on the educational level of the woman. Using again Germany as an example: the participation level of medium educated women without children rose from 83 percent to 86 percent, while the participation rate of medium educated women with children rose from 63 percent to 74 percent. As a result the effect of the child has 
become much lower: instead of twenty percent in 1992 the penalty is 'only' eleven percent in 1999. This pattern shows up for medium and high-educated women in all countries, the effects being largest in the Netherlands. In France and Italy a slight increase in the effect of children is found, mainly due to the fact that the participation rates of women without children increased. For the low-educated women, however, the picture is reverse: for all countries, except for Germany and the Netherlands, the effect of children increased, mainly due to the fact that the participation rates of women with children decreased. In Germany and the Netherlands, the participation rates of women with children increased more than the participation rates of women without children, resulting in a smaller effect of children. This finding supports the finding of Joshi et al. (1996) that mainly the high-educated women benefit from childcare provisions, leading to higher participation rates of high-educated women with children.

The results in Table 7 only show changes in participation rates due to changes in the behaviour of women with given characteristics. However, participation rates may well have changed due to changes in the composition of the population: even without changes in behaviour, changes in the average number of children, or their timing will result in a change in female labour supply. To split the effects of behaviour and characteristics, we will use a 'decomposition' to determine the relative contribution of all these changes to the total change in participation rates. We follow the approach of Van den Berg and Grift (2001), who analyzed the evolution of union membership over time. We compute predicted labour supply for the average individual in 1992 and change in a number of steps both the value of the explanatory variables and the estimated parameters to the values in 1999. For each step, we again compute predicted labour supply. As our explanatory variables are on three main issues, we use a decomposition in six steps. First we change the age, next the effect of the age, secondly we change the educational level and the effect of education on labour supply. Finally, we change the variables related to the family formation and composition and the effect of these on labour force participation.

Two remarks have to be made on this approach. Firstly, due to the fact that we use the average individual, we do only take into account changes in the average levels, and not the effects of changes in the distribution of the characteristics. Secondly, the results obtained are not unique: changing parameters and characteristics in a different order 
will lead to other predicted values. However, our main results are not affected by the ordering. As age merely reflects an effect of 'generation', which is exogenous to the woman, we change age as the first variable. Decisions on education are -in most casesmade before the decision on number and timing of children. Therefore, we change education as the second group of variables and children as the last one. The results of these computations are presented in Table 8.

\section{[Table 8]}

The Table should be read row by row: the first column in the table shows the participation rate of the average individual (which is not the average participation over all individuals). In Germany, the participation rate of the average 1992-individual is 59.6 percent. Changing the age to the average value in 1999 but keeping the effect of age at the 1992-value shows that due to the ageing of the population, participation levels go up slightly by 0.2 percentage points. However, the change between 1992 and 1999 in the age-participation profile, i.e., the behavioural change, leads to an increase in participation levels by about 4.6 percentage points, as reflected by the difference between the second and the third column of the Table. This increase in participation rates over the last decade due to a shift in the age-participation profile is observed in all countries, ranging from about 4 percentage points in Italy to 15 percentage points in the Netherlands. Comparing the size of this shift in the age-participation profile to the total change, it can be seen that for all countries, the change in the age-participation profile accounts for well over 80 percent of the total rise in female participation rates. For the Netherlands this is in accordance with the results of Henkens et al, (2002) who found that the change in participation rates is primarily due to a change in behaviour. This upward shift in the age-participation profile reflects a change in participation behaviour between cohorts. Given the age and the number of children women tend to work more in the late nineties than they did in the early nineties.

Turning to Germany again, the shift in the average educational level of the population did not have any effect on the participation level: the values in the fourth and third column are equal. However, Germany and the Netherlands form the exception: in the other countries the increase in educational level induced an increase in female labour force participation of about 4 percentage points. There is an effect of the change in 
behaviour: in Germany the change in behaviour leads to a decrease in the average participation level of almost 2 percentage points. This decrease in participation rates due to a change in behaviour is seen in all countries. As can also be seen from Table 7, the effect of being higher educated (relative to the medium level educated women) diminishes in all countries. In other words, the difference in labour force participation between the educational levels decreases. Due to social changes working for pay becomes common. This will hold for more and more groups, resulting in the fact that the educational level will be less and less an indicator for labour force participation. The effect of changes in educational levels and the changes in behaviour given this level did not contribute to overall changes in labour supply over the last decade. In total the effect of changes with respect to the educational level of women is even negative.

Finally, the model allows for computing both the effect of changes in the size and composition of families on female labour supply, as well as the effect of changing influence of these factors on labour supply. The difference between the 5th and the 6th column in Table 8 reflects the changes in labour supply due to changes in size and composition of families. These changes contribute positively to the overall increase in female labour force participation over the last decade. In other words, women (households) have changed their decisions with respect to the size and composition of families, which allowed them higher labour force participation. The size of this effect, however, is small and even non-existent in Germany. The difference between the 6th and the 7th column in the Table shows that labour force participation, given the size and composition of the average household, changed over the last decade. In Germany and the Netherlands female labour supply increased by about 3 percentage points as a result of this change in behaviour. So, children have become a less severe restriction on female labour force participation. This can be explained by the fact that Germany and the Netherlands have witnessed serious institutional changes over the last decades: changes on the labour market allowed for more part-time work in both countries, and in the Netherlands, the supply of formal childcare has increased enormously. Both changes together with a trend to try to induce women to maintain their economic independence even when married - results in the fact that work and family life can be reconciled more easily than in the past. In the southern countries however, there is a decrease in labour supply as a result of a change in behaviour. As female participation rates have been increasing all over Europe, the pressure on informal childcare provided by family 
members became higher. As a result a growing number of families will not succeed in finding proper childcare. It might be that in Spain, and to a lesser extent Italy, women attained increasingly higher educational levels, while at the same time the nucleus family replaced the extended family. This implies that the incentive to participate has become stronger, and at the same time, the possibility to get informal childcare has reduced. This, in turn, results in the fact that presence of (young) children has become a more important factor in the decision on labour force participation. In the UK, we do not see any signs of large changes in behaviour.

As the estimated effect of children is the 'combined effect' of preferences, social norms and restrictions the question is which of these three caused this decrease in participation rates. Part of the change may be found in the deteriorating economic situation in some of the countries included in this study, which has hit women with children harder than women without children, especially when childcare is expensive and not easily available. This may also be an additional explanation for the fact that in the Netherlands the effect of children became smaller: due to an increasing labour shortage childcare has become more available during the last decade, in order to pull women with children to the labour market (Remery, Van Doorne-Huiskes and Schippers, 2003). The second explanation may be that as a result of the increased level of education, the labour market situation of women improved. Therefore, they may choose to let their labour market participation more depend on their family situation. This can also explain the decrease in participation rates due to changes in characteristics in France and the UK: the relative improvement of women's labour market position due to an increased educational level gave women the opportunity to 'use' some of this gain to have more time for other activities besides work, i.e. children.

Overall, we must conclude that increases in participation rates could be attributed mainly to generational effects: given number and timing of children, married women from younger generations show higher participation levels than women from older generations. The influence of educational levels on the participation rates is contributing positively, but the size of this effect is relatively small compared to the generational effect. Finally, the effect of number and timing of children differs between countries: it contributed negatively in the southern countries, and positively in the northern countries. In Germany and the Netherlands only a part of the increase in participation 
rates was due to changes in the effects of children. These changes may be related to changes in the institutional context. As institutions such as childcare and taxexemptions are an important aspect of the restrictions we may therefore conclude that changes in these institutions helped increase female participation rates. However, although the effect is present, institutional changes are not the main factor in the increases that are observed over the last decade.

\section{Conclusions}

The last decade showed increasing female participation rates in Europe. Especially the participation rates of married women increased. This article aims at comparing female labour market participation between 1992 and 1999 for six European countries. To do so, we use data on (West-) Germany, Spain, France, Italy, the Netherlands and the United Kingdom from the European Labour Force Survey, provided by Eurostat.

Descriptive statistics show that next to participation behaviour, the characteristics of the population changed in several ways. In all countries, there has been a shift towards higher education and delay of family formation. Also, there seems to be an increase in the number of women that remain childless and the women that do not remain childless tend to have fewer children. All these changes may also contribute to the increase in female labour supply.

To discern between the relative weight of changing behaviour given characteristics and changing characteristics given behaviour, we estimate a logit model explaining female labour supply in the six countries in both years. The model is estimated on data from the European Labour Force Survey for 1992 and 1999. We use age, educational level and the number and age of their children as explanatory factors. The results are as expected: low-educated women work less than high-educated women, older women work less than younger women, and women without children show higher participation rates than women with children.

The models allow for predicting labour force participation rates given characteristics. Predicted rates show that participation rates have increased for women both with and without children, and for both low and high-educated women. On the other hand, the 
difference in labour supply between groups have changed: the differences between high and low educated women tend to have diminished: as working becomes more common in all European countries, the educational level becomes less and less important as a predictor for labour supply. Children remain an important factor for predicting labour supply, although in northern Europe (Germany and the Netherlands) their impact on labour supply slightly diminished. In southern Europe, the difference in labour supply between women with and without children even increased over the last decade.

This comparison of predicted labour supply does not account for changes in characteristics of the population: therefore, we also performed a decomposition analysis. The outcomes of this analysis suggest that education and child-related changes in participation rates are present but not very important. In all countries the rise in educational levels contributed to an increase in female labour supply. However, as participation became more and more 'normal' amongst all groups in society, the effect of educational level decreased in all countries. In all countries there has been a shift in fertility patterns, which resulted in a higher female labour supply. In other words, women are 'synchronizing' their labour and their care career, i.e. there is tendency among women to postpone the first child, have the children at shorter intervals, and choose a lower number of children as the 'completed family'. The result of this is an increase in female participation rates, not because the combination becomes easier, but because other choices are adapted to the fact that a paid job is preferred to having children. In Spain, Italy and France this increase in participation rates was more than counterbalanced by the fact that children became apparently more difficult to combine with work. In Germany, the Netherlands and the UK the increase in labour supply was even larger because in these countries the effect of children on labour supply became smaller, leading to higher participation rates given the number and age of children. As the effect of children is influenced by the institutions, we are led to the conclusion that especially in Germany and the Netherlands - changes in the institutions may have contributed to the increase in female labour force participation.

However, the main conclusion is that increases in female participation rates are primarily explained by the changing effects of age on female labour supply. As argued before, these effects should be interpreted as behavioural differences between generations (i.e. realized by changes in behaviour which are not explicitly related to 
children or educational level). In other words, we come to the conclusion that norms and values in society changed in such a way that the working wife has become more and more the standard in all European countries. This change in norms is reflected and perhaps stimulated by the change in organization of the welfare state: in many countries of the EU policies are aimed at increasing female participation rates by easing the combination of work and family. However, as we find no large contribution of the effect of children, we are led to the conclusion that although these policies may be important from the perspective of the household, they are more the result of changing labour supply patterns that the cause of it.

\section{Acknowledgements}

This research is part of the research program 'Levenslopen, transities en de combinatie van arbeid en zorg', financed by NWO (014-21-070-prog.d). This article also benefits from research financed by the European Union as part of the research project Female Employment and Fertility in National Institutional Contexts (FENICs), with contributions of the Universities of Nanterres, Bielefeld, Erlangen, Barcelona (Autonoma), Utrecht, and Warwick. (http://www.warwick.ac.uk/ier/fenics/index.html)

\section{Literature}

Dankmeyer, B., 1996, Long Run Opportunity-Costs of Children According to Education of the Mother in the Netherlands, Journal of Population Economics, 9, 349-361.

Den Dulk, L., 2001, Work-family Arrangements in Organisations. A cross-National Study in The Netherlands, Italy, The United Kingdom and Sweden, Rosenberg Publishers, Amsterdam.

Grift, Y. K., 1998, Female labour supply, the influence of taxes and social premiums, PhD-Thesis, Utrecht University, Utrecht.

Gustafsson, S., 1992, Separate Taxation and Married Women's Labor Supply: A Comparison of West Germany and Sweden, Journal of Population Economics, 5, 61-85.

Hakim, C., 1995, Five feminist myths about women's employment, British Journal of Sociology, 46, 429-455. 
Henkens, K, Y. Grift and J. Siegers, 2002, Changes in Female Labour Supply in the Netherlands 1989-1998: The Case of Married and Cohabiting Women, European Journal of Population, 18, 39-57.

Joshi, H., 1990, The cash alternative costs of childbearing: an approach to estimation using British data, Population Studies, 44, 41-60.

Joshi, H., 1994, The Foregone Earnings of Europe's Mothers, In Standards of Living and Families: Observation and Analysis, (Ed, Ekert-Jaffé, O.) John Libbey, London, 101-134.

Joshi, H., S. Macran and S. Dex, 1996, Employment after Childbearing and Women's Subsequent Labour Force Participation: Evidence from the British 1958 Birth Cohort, Journal of Population Economics, 9, 325-348.

Mertens, N., A. Van Doorne-Huiskes, J. J. Schippers and J. J. Siegers, 1998, Women's wage rates and the timing of children. A simultaneous analysis, Netherlands' Journal of Social Sciences, 34, 61-77.

Oaxaca, R., 1973, Male-Female Wage Differentials in Urban Labor Markets, International Economic Review, 14, 693-709.

Pott-Buter, H. A., 1993, Facts and fairy tales about female labor, family and fertility. A seven-country comparison, 1850-1990, Amsterdam University Press, Amsterdam.

Remery, C., A. Van Doorne-Huiskes and J. J. Schippers, 2003, Family-friendly policies in The Netherlands: the tripartite involvement, Personnel Review, 32, 456-473.

Rubery, J., M. Smith, C. Fagan and D. Grimshaw, 1998, Women and European Employment, Routledge, London, New York.

Van den Berg, A. and Y. Grift, 2001, Dutch Trade Union Membership 1979-1995, Applied Economics, 33, 1233-1242.

Vlasblom, J. D., 1998, Differences in labour supply and income of women in the Netherlands and the Federal Republic of Germany, A comparative analysis of the effect of taxes and social premiums, PhD-Thesis, Utrecht University, Utrecht.

Vlasblom, J. D., P. P. De Gijsel and J. J. Siegers, 2001, Taxes, Female Labour Supply and Household Income: Differences between the Netherlands and the Federal Republic of Germany, Applied Economics, 33, 735-744.

Vlasblom, J. D. and J. J. Schippers, 2002, The dynamics of female employment around childbirth, FENICs Report, Utrecht University, Utrecht. 
Wetzels, C. M. M. P., 1999, Squeezing Birth into Working Life, Household Panel Data Analyses Comparing Germany, Great-Britain, Sweden and The Netherlands, PhD-Thesis, University of Amsterdam, Amsterdam. 
Table 1

Educational level, women with partner, aged 25-59, 1992 and 1999

\begin{tabular}{|c|c|c|c|c|c|c|c|c|c|c|c|c|}
\hline & Germany & & \multicolumn{2}{|l|}{ Spain } & \multicolumn{2}{|l|}{ France } & \multicolumn{2}{|l|}{ Italy } & \multicolumn{2}{|c|}{ Netherlands } & \multicolumn{2}{|c|}{$\begin{array}{l}\text { United } \\
\text { Kingdom }\end{array}$} \\
\hline & 1992 & 1999 & 1992 & 1999 & 1992 & 1999 & 1992 & 1999 & 1992 & 1999 & 1992 & 1999 \\
\hline Low & 28 & 29 & 82 & 69 & 68 & 39 & 71 & 60 & 26 & 38 & 57 & 29 \\
\hline Medium & 61 & 57 & 9 & 14 & 18 & 39 & 24 & 32 & 57 & 43 & 26 & 48 \\
\hline High & 11 & 14 & 9 & 17 & 14 & 22 & 5 & 8 & 17 & 19 & 17 & 23 \\
\hline
\end{tabular}

Note that for the Netherlands and the UK, it seems as if Eurostat has changed recoding algorithms during the period.

The data show a break in 1995 for the Netherlands, and in 1998 for the UK. As a result the number of low educated women is too high in the Netherlands afterwards and too low in the UK.

Source: LFS, 1992/1999

Table 2

Percentage of women not having children in the household, by age category, 1992 and 1999

\begin{tabular}{|c|c|c|c|c|c|c|c|c|c|c|c|c|}
\hline & \multicolumn{2}{|c|}{ Germany } & \multicolumn{2}{|l|}{ Spain } & \multicolumn{2}{|l|}{ France } & \multicolumn{2}{|l|}{ Italy } & \multicolumn{2}{|c|}{ Netherlands } & \multicolumn{2}{|c|}{$\begin{array}{l}\text { United } \\
\text { Kingdom }\end{array}$} \\
\hline & 1992 & 1999 & 1992 & 1999 & 1992 & 1999 & 1992 & 1999 & 1992 & 1999 & 1992 & 1999 \\
\hline $25-29$ years & 38 & 46 & 27 & 41 & 34 & 48 & 25 & 34 & 61 & 71 & 43 & 50 \\
\hline 30-34 years & 20 & 28 & 10 & 19 & 13 & 17 & 13 & 20 & 27 & 31 & 24 & 26 \\
\hline 35-39 years & 14 & 16 & 4 & 8 & 8 & 8 & 6 & 11 & 16 & 17 & 15 & 15 \\
\hline $40-44$ years & 19 & 18 & 4 & 5 & 12 & 9 & 7 & 7 & 12 & 13 & 15 & 17 \\
\hline $45-49$ years & 31 & 32 & 5 & 5 & 28 & 24 & 9 & 9 & 22 & 24 & 29 & 30 \\
\hline $50-54$ years & 47 & 53 & 11 & 11 & 50 & 49 & 19 & 16 & 45 & 53 & 49 & 53 \\
\hline $55-59$ years & 64 & 73 & 26 & 25 & 68 & 71 & 36 & 31 & 66 & 77 & 68 & 74 \\
\hline Age at first birth & 25.9 & 26.5 & 25.9 & 26.2 & 25.4 & 26.2 & 25.8 & 26.0 & 26.6 & 27.5 & 26.0 & 27.0 \\
\hline
\end{tabular}

Source: LFS, 1992-1999 
Table 3

The average number of children present in the household, by age category of the woman, 1992 and 1999

\begin{tabular}{|c|c|c|c|c|c|c|c|c|c|c|c|c|}
\hline & \multicolumn{2}{|c|}{ Germany } & \multicolumn{2}{|l|}{ Spain } & \multicolumn{2}{|l|}{ France } & \multicolumn{2}{|l|}{ Italy } & \multicolumn{2}{|c|}{ Netherlands } & \multicolumn{2}{|c|}{$\begin{array}{l}\text { United } \\
\text { Kingdom }\end{array}$} \\
\hline & 1992 & 1999 & 1992 & 1999 & 1992 & 1999 & 1992 & 1999 & 1992 & 1999 & 1992 & 1999 \\
\hline $25-29$ years & 1.0 & 0.9 & 1.1 & 0.8 & 1.1 & 0.8 & 1.1 & 0.9 & 0.6 & 0.5 & 1.0 & 0.8 \\
\hline $30-34$ years & 1.5 & 1.3 & 1.7 & 1.3 & 1.8 & 1.6 & 1.5 & 1.3 & 1.4 & 1.2 & 1.6 & 1.5 \\
\hline $35-39$ years & 1.7 & 1.7 & 2.1 & 1.8 & 2.0 & 2.0 & 1.8 & 1.6 & 1.9 & 1.8 & 1.9 & 1.8 \\
\hline 40-44 years & 1.5 & 1.6 & 2.3 & 2.0 & 1.8 & 2.0 & 1.8 & 1.8 & 1.9 & 1.9 & 1.8 & 1.7 \\
\hline $45-49$ years & 1.2 & 1.2 & 2.3 & 2.1 & 1.3 & 1.4 & 1.7 & 1.7 & 1.4 & 1.5 & 1.3 & 1.3 \\
\hline $50-54$ years & 0.8 & 0.7 & 2.0 & 1.8 & 0.8 & 0.8 & 1.4 & 1.5 & 0.8 & 0.7 & 0.7 & 0.7 \\
\hline $55-59$ years & 0.5 & 0.4 & 1.4 & 1.4 & 0.5 & 0.4 & 1.0 & 1.1 & 0.4 & 0.3 & 0.4 & 0.3 \\
\hline
\end{tabular}

Source: LFS, 1992/1999

Table 4

Percentage of married woman aged 25-59 working for pay, 1992 and 1999

\begin{tabular}{|c|c|c|c|c|c|c|c|c|c|c|c|c|}
\hline & \multicolumn{2}{|c|}{ Germany } & \multicolumn{2}{|l|}{ Spain } & \multicolumn{2}{|l|}{ France } & \multicolumn{2}{|l|}{ Italy } & \multicolumn{2}{|c|}{ Netherlands } & \multicolumn{2}{|c|}{$\begin{array}{l}\text { United } \\
\text { Kingdom }\end{array}$} \\
\hline & 1992 & 1999 & 1992 & 1999 & 1992 & 1999 & 1992 & 1999 & 1992 & 1999 & 1992 & 1999 \\
\hline $25-29$ years & 61 & 65 & 35 & 49 & 65 & 65 & 42 & 42 & 69 & 81 & 66 & 76 \\
\hline $30-34$ years & 57 & 65 & 38 & 48 & 63 & 65 & 48 & 49 & 57 & 72 & 64 & 73 \\
\hline $35-39$ years & 61 & 65 & 37 & 46 & 66 & 69 & 50 & 51 & 58 & 71 & 70 & 74 \\
\hline 40-44 years & 65 & 69 & 35 & 46 & 68 & 71 & 48 & 51 & 57 & 68 & 75 & 77 \\
\hline 45-49 years & 63 & 69 & 27 & 39 & 65 & 71 & 41 & 46 & 49 & 69 & 77 & 80 \\
\hline $50-54$ years & 55 & 62 & 25 & 30 & 57 & 66 & 31 & 36 & 41 & 52 & 69 & 73 \\
\hline $55-59$ years & 40 & 45 & 19 & 22 & 39 & 43 & 17 & 22 & 25 & 34 & 56 & 57 \\
\hline Total & 57 & 63 & 31 & 40 & 61 & 65 & 40 & 43 & 53 & 65 & 69 & 73 \\
\hline
\end{tabular}

Working for pay: defined as working at least one hour in reference week

Source: LFS, 1992/1999 
Table 5

Estimation results from the logit model on female participation rates per country, 1992.

\begin{tabular}{|c|c|c|c|c|c|c|}
\hline & $\begin{array}{l}\text { West } \\
\text { Germany }\end{array}$ & Spain & France & Italy & Netherlands & $\begin{array}{l}\text { United } \\
\text { Kingdom }\end{array}$ \\
\hline Constant & $\begin{array}{l}0.460 \\
(0.35)\end{array}$ & $\begin{array}{l}-3.457^{* *} \\
(0.46)\end{array}$ & $\begin{array}{l}-2.790 * * \\
(0.37)\end{array}$ & $\begin{array}{l}-5.024 * * \\
(0.40)\end{array}$ & $\begin{array}{c}-0.312 \\
(0.64)\end{array}$ & $\begin{array}{l}-0.142 \\
(0.43)\end{array}$ \\
\hline Age & $\begin{array}{l}0.121^{* *} \\
(0.02)\end{array}$ & $\begin{array}{l}0.218 * * \\
(0.02)\end{array}$ & $\begin{array}{l}0.244 * * \\
(0.02)\end{array}$ & $\begin{array}{l}0.352 * * \\
(0.02)\end{array}$ & $\begin{array}{l}0.171 * * \\
(0.03)\end{array}$ & $\begin{array}{l}0.140 * * \\
(0.02)\end{array}$ \\
\hline Age squared/100 & $\begin{array}{l}-0.233 * * \\
(0.02)\end{array}$ & $\begin{array}{l}-0.301 * * \\
(0.03)\end{array}$ & $\begin{array}{l}-0.345^{* *} \\
(0.02)\end{array}$ & $\begin{array}{l}-0.490 * * \\
(0.02)\end{array}$ & $\begin{array}{l}-0.321^{* *} \\
(0.04)\end{array}$ & $\begin{array}{l}-0.227 * * \\
(0.02)\end{array}$ \\
\hline Low educated & $\begin{array}{l}-0.396^{* *} \\
(0.03)\end{array}$ & $\begin{array}{l}-0.741 * * \\
(0.05)\end{array}$ & $\begin{array}{l}-0.376^{* *} \\
(0.04)\end{array}$ & $\begin{array}{l}-1.016^{* *} \\
(0.03)\end{array}$ & $\begin{array}{l}-0.519 * * \\
(0.05)\end{array}$ & $\begin{array}{l}-0.395 * * \\
(0.03)\end{array}$ \\
\hline High educated & $\begin{array}{l}0.517 * * \\
(0.04)\end{array}$ & $\begin{array}{l}1.036 * * \\
(0.07)\end{array}$ & $\begin{array}{l}0.613 * * \\
(0.05)\end{array}$ & $\begin{array}{l}1.020 * * \\
(0.07)\end{array}$ & $\begin{array}{l}0.886^{* *} \\
(0.06)\end{array}$ & $\begin{array}{l}0.578 * * \\
(0.05)\end{array}$ \\
\hline Effect first child & $\begin{array}{l}-2.822 * * \\
(0.09)\end{array}$ & $\begin{array}{l}-0.884 * * \\
(0.12)\end{array}$ & $\begin{array}{l}-0.955^{* *} \\
(0.09)\end{array}$ & $\begin{array}{l}-1.151^{* *} \\
(0.10)\end{array}$ & $\begin{array}{l}-2.917^{* *} \\
(0.14)\end{array}$ & $\begin{array}{l}-2.461 * * \\
(0.10)\end{array}$ \\
\hline $\begin{array}{l}\text { Effect subsequent } \\
\text { children }\end{array}$ & $\begin{array}{l}-1.229 * * \\
(0.08)\end{array}$ & $\begin{array}{l}-0.560 * * \\
(0.09)\end{array}$ & $\begin{array}{l}-1.337^{* *} \\
(0.08)\end{array}$ & $\begin{array}{l}-1.190^{* *} \\
(0.10)\end{array}$ & $\begin{array}{l}-1.498 * * \\
(0.12)\end{array}$ & $\begin{array}{l}-1.210 * * \\
(0.09)\end{array}$ \\
\hline $\begin{array}{l}\text { Age*number of } \\
\text { children } / 10\end{array}$ & $\begin{array}{l}0.224 * * \\
(0.02)\end{array}$ & $\begin{array}{l}0.094 * * \\
(0.02)\end{array}$ & $\begin{array}{l}0.172 * * \\
(0.02)\end{array}$ & $\begin{array}{l}0.197 * * \\
(0.02)\end{array}$ & $\begin{array}{l}0.338^{* *} \\
(0.03)\end{array}$ & $\begin{array}{l}0.229 * * \\
(0.02)\end{array}$ \\
\hline Age youngest child & $\begin{array}{l}0.168 * * \\
(0.01)\end{array}$ & $\begin{array}{l}0.026 \\
(0.02)\end{array}$ & $\begin{array}{l}0.128^{* *} \\
(0.01)\end{array}$ & $\begin{array}{l}-0.008 \\
(0.01)\end{array}$ & $\begin{array}{l}0.099 * * \\
(0.02)\end{array}$ & $\begin{array}{l}0.251 * * \\
(0.02)\end{array}$ \\
\hline $\begin{array}{l}\text { Age } * \text { age youngest } \\
\text { child/100 }\end{array}$ & $\begin{array}{l}-0.193 * * \\
(0.02)\end{array}$ & $\begin{array}{l}-0.027 \\
(0.03)\end{array}$ & $\begin{array}{l}-0.229 * * \\
(0.03)\end{array}$ & $\begin{array}{r}0.027 \\
(0.03)\end{array}$ & $\begin{array}{l}-0.118^{* *} \\
(0.05)\end{array}$ & $\begin{array}{l}-0.357 * * \\
(0.03)\end{array}$ \\
\hline $\begin{array}{l}\text { Age difference } \\
\text { youngest - oldest } \\
\text { child/10 }\end{array}$ & $\begin{array}{l}0.390 * * \\
(0.06)\end{array}$ & $\begin{array}{l}-0.045 \\
(0.07)\end{array}$ & $\begin{array}{l}0.241^{* *} \\
(0.07)\end{array}$ & $\begin{array}{l}0.022 \\
(0.06)\end{array}$ & $\begin{array}{l}-0.223^{*} \\
(0.13)\end{array}$ & $\begin{array}{l}0.215^{* *} \\
(0.08)\end{array}$ \\
\hline $\log \mathrm{L}$ & -6805.9 & -6637.9 & -6007.6 & -6705.5 & -3553.7 & -5174.6 \\
\hline $\begin{array}{l}\text { \# individuals } \\
(* 10 \mathrm{E} 6)\end{array}$ & 10.78 & 6.10 & 10.21 & 9.49 & 2.99 & 9.86 \\
\hline \# data cells & 11,019 & 11,660 & 9,965 & 11,238 & 6,005 & 9,218 \\
\hline
\end{tabular}

The reference category for education level is 'intermediate level of education'.

Heteroscedastic consistent standard errors in parenthesis. **: significant at $1 \%$

Source: LFS 1992, own computations. 
Table 6

Estimation results from the logit model on female participation rates per country, 1999

\begin{tabular}{|c|c|c|c|c|c|c|}
\hline & $\begin{array}{l}\text { West } \\
\text { Germany }\end{array}$ & Spain & France & Italy & Netherlands & $\begin{array}{l}\text { United } \\
\text { Kingdom }\end{array}$ \\
\hline Constant & $\begin{array}{l}-0.753 \\
(0.37)\end{array}$ & $\begin{array}{l}-2.354 * * \\
(0.47)\end{array}$ & $\begin{array}{l}-5.153^{* *} \\
(0.47)\end{array}$ & $\begin{array}{l}-6.365^{* *} \\
(0.46)\end{array}$ & $\begin{array}{l}-1.544 * \\
(0.77)\end{array}$ & $\begin{array}{l}0.166 \\
(0.54)\end{array}$ \\
\hline Age & $\begin{array}{l}0.176^{* *} \\
(0.02)\end{array}$ & $\begin{array}{l}0.189 * * \\
(0.02)\end{array}$ & $\begin{array}{l}0.359 * * \\
(0.02)\end{array}$ & $\begin{array}{l}0.416 * * \\
(0.02)\end{array}$ & $\begin{array}{l}0.255^{* *} \\
(0.04)\end{array}$ & $\begin{array}{l}0.142 * * \\
(0.03)\end{array}$ \\
\hline Age squared/100 & $\begin{array}{l}-0.282 * * \\
(0.02)\end{array}$ & $\begin{array}{l}-0.275^{* *} \\
(0.03)\end{array}$ & $\begin{array}{l}-0.470 * * \\
(0.03)\end{array}$ & $\begin{array}{l}-0.553^{* *} \\
(0.03)\end{array}$ & $\begin{array}{l}-0.410^{* *} \\
(0.05)\end{array}$ & $\begin{array}{l}-0.233^{* *} \\
(0.03)\end{array}$ \\
\hline Low educated & $\begin{array}{l}-0.660 * * \\
(0.03)\end{array}$ & $\begin{array}{l}-0.745^{* *} \\
(0.04)\end{array}$ & $\begin{array}{l}-0.581 * * \\
(0.04)\end{array}$ & $\begin{array}{l}-1.098^{* *} \\
(0.03)\end{array}$ & $\begin{array}{l}-0.784^{* *} \\
(0.06)\end{array}$ & $\begin{array}{l}-0.821^{* *} \\
(0.04)\end{array}$ \\
\hline High educated & $\begin{array}{l}0.510^{* *} \\
(0.04)\end{array}$ & $\begin{array}{l}0.906 * * \\
(0.06)\end{array}$ & $\begin{array}{l}0.582 * * \\
(0.05)\end{array}$ & $\begin{array}{l}0.897 * * \\
(0.06)\end{array}$ & $\begin{array}{l}0.697 * * \\
(0.09)\end{array}$ & $\begin{array}{l}0.571 * * \\
(0.06)\end{array}$ \\
\hline Effect first child & $\begin{array}{l}-2.402 * * \\
(0.08)\end{array}$ & $\begin{array}{l}-1.407^{* *} \\
(0.10)\end{array}$ & $\begin{array}{l}-1.274 * * \\
(0.10)\end{array}$ & $\begin{array}{l}-1.356^{* *} \\
(0.10)\end{array}$ & $\begin{array}{l}-2.319 * * \\
(0.18)\end{array}$ & $\begin{array}{l}-2.383^{* *} \\
(0.11)\end{array}$ \\
\hline $\begin{array}{l}\text { Effect subsequent } \\
\text { children }\end{array}$ & $\begin{array}{l}-1.224 * * \\
(0.08)\end{array}$ & $\begin{array}{l}-0.881 * * \\
(0.10)\end{array}$ & $\begin{array}{l}-1.291 * * \\
(0.08)\end{array}$ & $\begin{array}{l}-1.543^{* *} \\
(0.10)\end{array}$ & $\begin{array}{l}-1.598 * * \\
(0.16)\end{array}$ & $\begin{array}{l}-1.308^{* *} \\
(0.10)\end{array}$ \\
\hline $\begin{array}{l}\text { Age*number of } \\
\text { children } / 10\end{array}$ & $\begin{array}{l}0.219 * * \\
(0.02)\end{array}$ & $\begin{array}{l}0.159 * * \\
(0.02)\end{array}$ & $\begin{array}{l}0.169 * * \\
(0.02)\end{array}$ & $\begin{array}{l}0.255^{* *} \\
(0.02)\end{array}$ & $\begin{array}{l}0.337^{* *} \\
(0.04)\end{array}$ & $\begin{array}{l}0.248 * * \\
(0.02)\end{array}$ \\
\hline Age youngest child & $\begin{array}{l}0.173^{* *} \\
(0.01)\end{array}$ & $\begin{array}{l}0.072 * * \\
(0.02)\end{array}$ & $\begin{array}{l}0.158 * * \\
(0.02)\end{array}$ & $\begin{array}{l}-0.057 * * \\
(0.02)\end{array}$ & $\begin{array}{l}0.033 \\
(0.03)\end{array}$ & $\begin{array}{l}0.207^{* *} \\
(0.02)\end{array}$ \\
\hline $\begin{array}{l}\text { Age * age youngest } \\
\text { child/100 }\end{array}$ & $\begin{array}{l}-0.235^{* *} \\
(0.03)\end{array}$ & $\begin{array}{l}-0.113 * * \\
(0.03)\end{array}$ & $\begin{array}{l}-0.253 * * \\
(0.04)\end{array}$ & $\begin{array}{l}0.106^{* *} \\
(0.03)\end{array}$ & $\begin{array}{l}-0.028 \\
(0.06)\end{array}$ & $\begin{array}{l}-0.286^{* *} \\
(0.04)\end{array}$ \\
\hline $\begin{array}{l}\text { Age difference } \\
\text { youngest - oldest } \\
\text { child/10 }\end{array}$ & $\begin{array}{l}0.170 * * \\
(0.06)\end{array}$ & $\begin{array}{l}0.027 \\
(0.07)\end{array}$ & $\begin{array}{l}0.200 * * \\
(0.07)\end{array}$ & $\begin{array}{l}0.094 \\
(0.06)\end{array}$ & $\begin{array}{l}-0.176 \\
(0.17)\end{array}$ & $\begin{array}{l}0.195 * \\
(0.09)\end{array}$ \\
\hline $\log \mathrm{L}$ & -6856.1 & -7068.5 & -6244.6 & -6597.2 & -2618.2 & -4293.6 \\
\hline $\begin{array}{l}\text { \# individuals } \\
(* 10 \mathrm{E} 6)\end{array}$ & 11.98 & 6.21 & 10.47 & 9.57 & 3.18 & 9.85 \\
\hline \# data cells & 11,564 & 11,716 & 10,817 & 10,082 & 4,763 & 8,283 \\
\hline
\end{tabular}

The reference category for education level is 'intermediate level of education'.

Heteroscedastic consistent standard errors in parenthesis. **: significant at $1 \%$, *: significant at $5 \%$ Source: LFS 1999, own computations. 
Table 7

Predicted participation rates for selected women aged 40

\begin{tabular}{|c|c|c|c|c|c|c|c|c|c|c|c|c|}
\hline & \multicolumn{2}{|c|}{$\begin{array}{l}\text { West } \\
\text { Germany }\end{array}$} & \multicolumn{2}{|c|}{ Spain } & \multicolumn{2}{|c|}{ France } & \multicolumn{2}{|c|}{ Italy } & \multicolumn{2}{|c|}{$\begin{array}{l}\text { Nether- } \\
\text { lands }\end{array}$} & \multicolumn{2}{|c|}{$\begin{array}{l}\text { United } \\
\text { Kingdom }\end{array}$} \\
\hline & 92 & 99 & 92 & 99 & 92 & 99 & 92 & 99 & 92 & 99 & 92 & 99 \\
\hline \multicolumn{13}{|l|}{ Low educated } \\
\hline no children & 76 & 75 & 43 & 51 & 74 & 76 & 55 & 58 & 70 & 79 & 81 & 78 \\
\hline one child, aged 10 years & 54 & 59 & 34 & 39 & 76 & 75 & 47 & 46 & 45 & 63 & 72 & 70 \\
\hline two children, aged 5 and 10 & 39 & 43 & 28 & 31 & 61 & 57 & 37 & 36 & 33 & 52 & 56 & 54 \\
\hline \multicolumn{13}{|l|}{ Medium educated } \\
\hline no children & 83 & 86 & 61 & 69 & 81 & 85 & 77 & 80 & 80 & 89 & 86 & 89 \\
\hline one child, aged 10 years & 63 & 74 & 52 & 58 & 82 & 84 & 71 & 72 & 58 & 79 & 80 & 84 \\
\hline two children, aged 5 and 10 & 49 & 59 & 45 & 48 & 69 & 71 & 62 & 63 & 45 & 71 & 65 & 72 \\
\hline \multicolumn{13}{|l|}{ High educated } \\
\hline no children & 89 & 91 & 82 & 85 & 89 & 91 & 91 & 91 & 91 & 94 & 92 & 94 \\
\hline one child, aged 10 & 74 & 83 & 76 & 77 & 89 & 91 & 87 & 86 & 77 & 88 & 87 & 90 \\
\hline two children, aged 5 and 10 & 62 & 71 & 70 & 70 & 81 & 81 & 82 & 81 & 67 & 83 & 77 & 82 \\
\hline
\end{tabular}

Source: own computations

\section{Table 8}

Decomposition results for the changes over the last decade

\begin{tabular}{|c|c|c|c|c|c|c|c|c|}
\hline \multirow[t]{3}{*}{ Parameters } & \multirow[t]{3}{*}{1992} & & \multicolumn{2}{|c|}{ Age 1999} & \multicolumn{2}{|c|}{ Age 1999} & 1999 & \multirow{2}{*}{$\begin{array}{l}\text { Total } \\
\text { differ- }\end{array}$} \\
\hline & & & \multicolumn{2}{|c|}{ Education 1992} & \multicolumn{2}{|c|}{ Education 1999} & & \\
\hline & & & \multicolumn{2}{|c|}{ Children 1992} & \multicolumn{2}{|c|}{ Children 1992} & & ence \\
\hline \multirow[t]{4}{*}{ Characteristics } & \multirow[t]{3}{*}{1992} & \multicolumn{2}{|c|}{ Age 1999} & \multicolumn{2}{|c|}{ Age 1999} & \multicolumn{2}{|l|}{1999} & \\
\hline & & \multicolumn{2}{|c|}{ Education 1992} & \multicolumn{3}{|c|}{ Education 1999} & & \\
\hline & & \multicolumn{2}{|c|}{ Children 1992} & \multicolumn{3}{|c|}{ Children 1992} & & \\
\hline & (1) & (2) & (3) & (4) & $(5)$ & (6) & (7) & (8) \\
\hline West Germany & 59.6 & 59.8 & 64.4 & 64.6 & 62.8 & 62.8 & 65.4 & 5.8 \\
\hline Spain & 29.9 & 30.2 & 38.0 & 42.3 & 41.7 & 43.2 & 39.6 & 9.7 \\
\hline France & 62.9 & 62.5 & 66.9 & 70.2 & 68.4 & 69.1 & 67.4 & 4.5 \\
\hline Italy & 39.3 & 40.1 & 43.8 & 47.4 & 46.0 & 46.9 & 43.3 & 4.0 \\
\hline Netherlands & 55.1 & 53.3 & 68.1 & 67.5 & 64.5 & 66.0 & 69.3 & 14.2 \\
\hline $\begin{array}{l}\text { United King- } \\
\text { dom }\end{array}$ & 71.1 & 70.2 & 75.6 & 78.2 & 76.0 & 76.3 & 76.4 & 5.3 \\
\hline
\end{tabular}

Source: LFS 1992, 1999, own computations 